\title{
A new study of Brazilian concrete strength conformance
}

\section{Um novo estudo da conformidade da resistência do concreto produzido no Brasil}
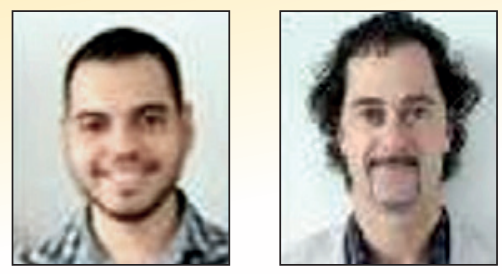

W. C. SANTIAGO ab wagner.santiago@univasf.edu.br

A. T. BECK b atbeck@sc.usp.br

\begin{abstract}
This paper presents a new evaluation of the strength compliance of concretes produced in Brazil. It is based on experimental results of over twenty-seven thousand concrete samples from different parts of the country. Results show that a significant part of Brazilian concrete do not reach the characteristic strength (fck) specified in design, and the percentage of nonconforming samples tend to be higher than $5 \%$. This study also reveals the concrete produced in the South and Midwest regions have less variability than the ones produced in the other regions of the country. These results emphasize the importance of a rigorous control in manufacturing and reception of concretes in order to reduce the nonconforming cases.
\end{abstract}

Keywords: concrete strength compliance, concrete structures, structural safety.

\section{Resumo}

Este artigo apresenta uma nova avaliação da conformidade dos concretos atualmente produzidos no Brasil. Ela está pautada em resultados de ensaios de resistência à compressão axial de mais de vinte e sete mil corpos de prova de concretos moldados in loco, no ato de seu recebimento, em diferentes obras do país. Os resultados mostram que parte do concreto produzido no Brasil não alcança a resistência característica (fck) prevista em projeto, e que o percentual de amostras não conformes tende a ser superior a $5 \%$. Este estudo também evidencia que os concretos produzidos nas regiões Sul e Centro-Oeste apresentam menor variabilidade que aqueles produzidos nas demais regiões do país. Estes resultados reforçam a importância de um controle rigoroso na fabricação e no recebimento do concreto visando diminuir a ocorrência de não conformidades.

Palavras-chave: conformidade da resistência do concreto, estruturas de concreto, segurança das estruturas. 


\section{Introduction}

This article presents an investigation about the strength compliance of concretes manufactured in different states from the five geographic regions of Brazil. It is based on results from axial compression strength tests at 28 days of age performed in more than 27 thousand cylindrical specimens of concrete molded in loco.

This study divides the data into 4 classes - C20, C30, C40 and C50 - in order to evaluate the conformance of the concrete as a function of its characteristic strength. The analysis are performed both at regional and national levels. As part of this work, comparisons are made between these results and the results shared by Santiago and Beck five years ago [1].

It is important to emphasize the entire study is based on current national normalization, specially the codes for compression test of concrete cylindrical specimens [2], preparation, control and acceptance of concrete [3] and the design of concrete structures [4]. This work is part of a larger project about the calibration, based on structural reliability, of the partial factors from Brazilian design codes. The calibration is being developed by the authors of this paper, though it has already been addressed in a preliminary way by Beck and Doria [5], Beck et al. [6], Chaves et al. [7] and Beck and Souza Jr. [8].

\section{Compressive strength of concrete}

The compressive strength of concrete is random by nature, its variability is a result from the constituent materials, test procedures, production and operation equipments. The necessary measures to reduce variability involves the quality control of each one of the variables and the more efficient it is, the more homogeneous is the concrete produced [9].

The concrete production involves its dosage which is the process used to obtain the best proportion between cement, aggregates, water, additives and addition in order to meet certain specifications [10]. Concrete's preparation, control and acceptance code [3] establish three preparation conditions: condition A (applied to all classes), condition B (applied to classes C10 and C20) and condition C (applied to classes C10 and C15).

Once produced, the concrete is submitted to a quality control that test the cylindrical specimens at 28 days, in order to verify its compressive strength. Concrete's preparation, control and acceptance code [3] allows the control to be by total or partial sampling. In

\section{Table 1}

Quantification of the specimens by Brazilian regions

\begin{tabular}{|c|c|c|}
\hline Region & Quantity & Percentage \\
\hline CO & 4857 & 17 \\
\hline S & 2222 & 8 \\
\hline SE & 16612 & 60 \\
\hline N & 300 & 14 \\
\hline NE & 3814 & 1 \\
\hline Total & 27805 & 100 \\
\hline
\end{tabular}

the control by total sampling two specimens are molded for each concrete batch, while in the control by partial sampling at least six specimens are molded for each 50 or $100 \mathrm{~m} 3$ of concrete used on the structure.

At the end of the quality control, a batch is considered conform when the estimate value of its characteristic strength (fckest), referred to a (known) sampling of a (unknown) population, satisfies the relation presented in Eq. (1). It is worth mentioning the characteristic strength (fck) of the concrete is a reference value, which have to be reach by at least $95 \%$ of the specimens tested.

$\mathrm{f}_{\text {ckest }} \geq \mathrm{f}_{\text {ck }}$

Although the compressive strength test in specimens is an evidence of quality of the concrete, its result is restricted to indicate a potential strength of the population based on sampling. Accordingly, a concrete is considered conform when less than $5 \%$ of its samples present a compressive strength value below the predicted one.

The issue of the conformity of structural concretes produced in Brazil has been the object of several studies, but it still needs to be further developed. Among the studies carried out, stand out Magalhães et al [11], Santiago and Beck [1], Silva Filho and Helene [12], Castro [13], Borges [14] and Vieira Filho [15].

Some studies also indicate the dosing plants are centralizing the dosage strength in the characteristic strength and not in the average strength $[1,16]$; which is probably the main reason for the frequent occurrences of nonconforming concrete in Brazilian construction sites. In this scenario, this study present a statistic description that represents the set of concrete produced in Brazil, given the analysis are performed from samples collected and tested in the same conditions established by a code applied throughout the country.

\section{Origin and database classification}

The present work is subsidized with information about the compressive strength at 28 days of over 27 thousand cylindrical specimens $-10 \mathrm{~cm}$ diameter and $20 \mathrm{~cm}$ height - of concretes molded in loco in constructions sites from the five Brazilian geographical regions - Midwest (CO), South (S), Southeast (SE), North (N) and Northeast (NE) - referring to the 15 federative units. Table 1 shows a quantification of the specimens according to the different regions. In accordance with the concrete's preparation, control and acceptance code [3], the concrete studied were produced with condition A of preparation between 2011 and 2016 at authorized dosing plants, and certified technological-control companies controlled it by total sampling.

\section{Table 2}

Quantification of the specimens by strength class

\begin{tabular}{|c|c|c|}
\hline Class & Quantity & Percentage \\
\hline C20 & 3866 & 14 \\
\hline C30 & 6685 & 24 \\
\hline C40 & 3982 & 14 \\
\hline C50 & 13272 & 48 \\
\hline Total & 27805 & 100 \\
\hline
\end{tabular}




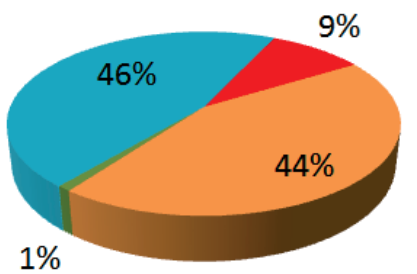

$\mathrm{CO} \square \mathrm{S} \square \mathrm{SE} \square \mathrm{N}$

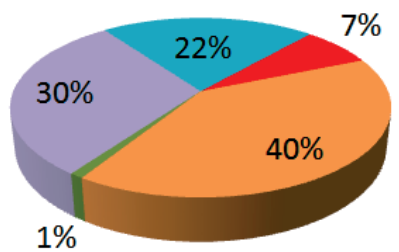

$\square \mathrm{CO} \square \mathrm{S} \square \mathrm{SE} \square \mathrm{N} \square \mathrm{NE}$

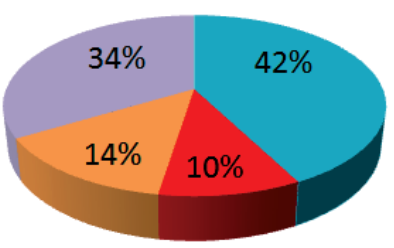

$\square \mathrm{CO} \square \mathrm{S} \square \mathrm{SE} \square \mathrm{NE}$

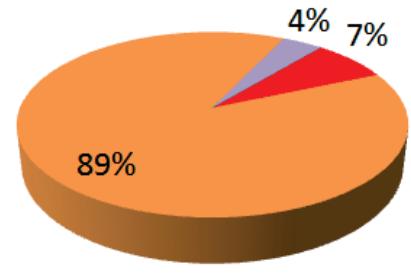

$\square \mathrm{S} \quad \mathrm{SE} \quad \mathrm{NE}$

\section{C20 concrete}

B $\mathrm{C} 30$ concrete

C 40 concrete

D C50 concrete

Figure 1

Percentage of sampling data according to the brazilian regions

In order to evaluate the behavior of the concrete in relation to its characteristic strength, the data were classified into 4 classes - C20, C30, C40 and C50 - according to the information available in the technological control reports. Table 2 presents a brief quantification of the tested specimens according to the evaluated strength classes. Figure 1 shows the percentage distribution of the data according to the geographical regions of the country for each one of the four strength classes of concrete studied in this work. The results expressed in the graphics have a strong relation with the strength classes usually used in each region.

In addition, the data used were obtained from the following companies, educational institutes and laboratories: AJL Engenharia,
Centro de Tecnologia da UFAL, CONSULTARE Laboratório, CSP Projetos e Consultoria, EGELTE Engenharia, ITAPIPU BINACIONAL, Laboratório de Ensaios de Materiais da FACENS, MPA Controle Tecnológico, SENAI-DF, SILCO Engenharia, TECNOL Tecnologia em Concreto, TECNOCON Engenharia e VENTUSCORE Soluções em Concreto.

\section{Database treatment}

The randomness nature of concrete strength requires a statistical approach for the problem. Thus, based on the samples, average strength $\left(f_{c m}\right)$, estimated characteristic strength $\left(f_{\text {ckest }}\right)$, standard de-
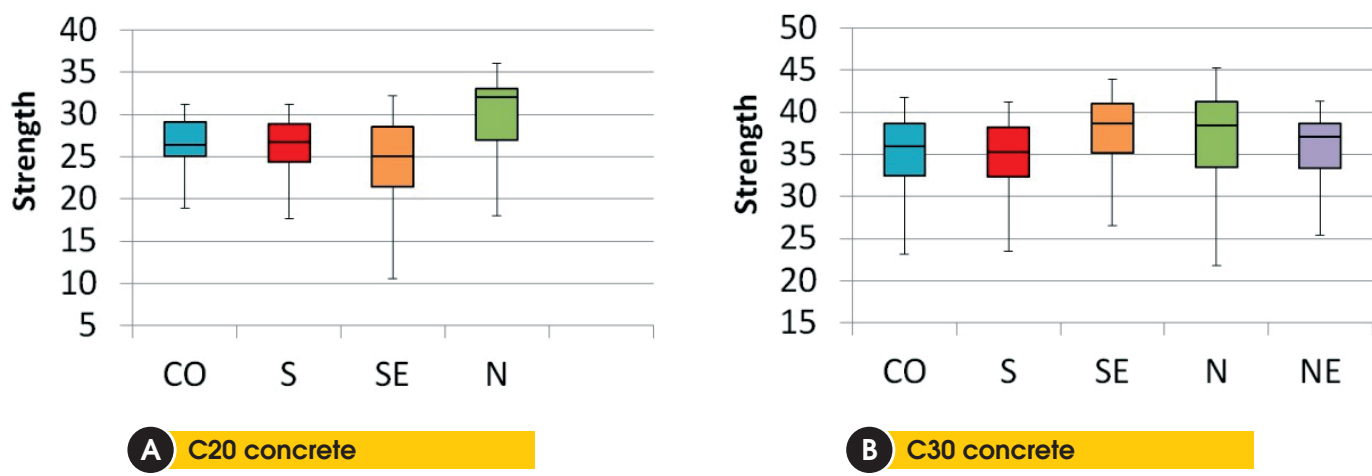

B C30 concrete
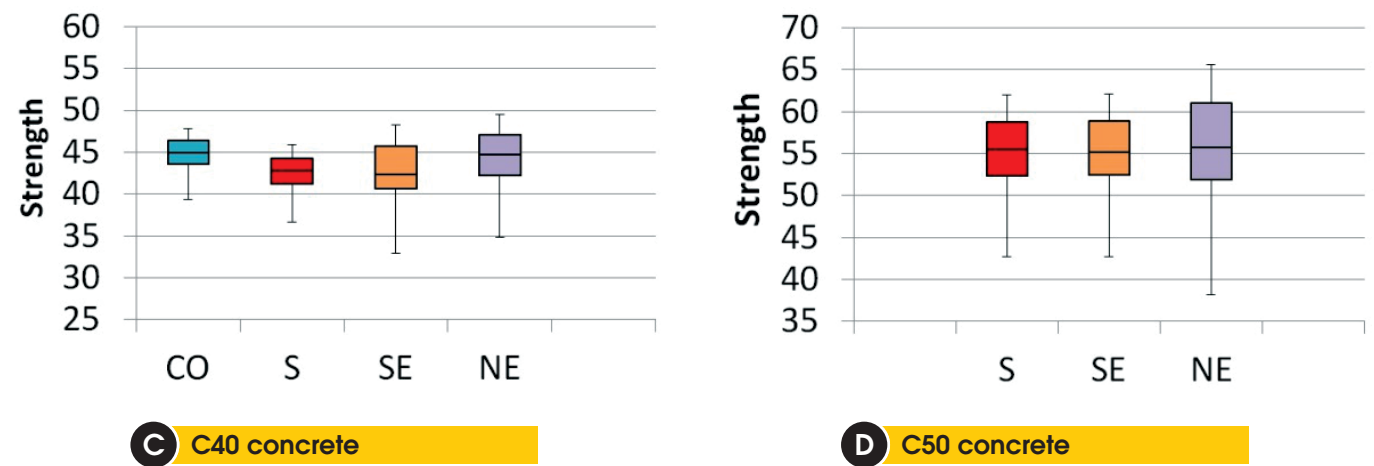

Figure 2

Box-and-whiskers representation for the samples according to the regions 
viation $(\sigma)$, variation coefficient (Cve) and the probability distribution curve were determined.

If $\mathrm{n}$ is the total number of samples and $\mathrm{f}_{\mathrm{i}}$ each one of the values $(i=1,2,3, \ldots, n)$, the average strength $\left(f_{c m}\right)$ was calculated through the sum of all samples divided by the total number as it is shown in Eq. 2. From the increasing order of the samples $\left(f_{1}\right.$ $<\mathrm{f}_{2}<\mathrm{f}_{3}<\ldots<\mathrm{f}_{\mathrm{n}}$ ) it was possible to estimate the characteristic strength $\left(f_{\text {ckest }}\right)$ based on the result corresponding to $5 \%$ percentile, see Eq. 3.

$\mathrm{f}_{\mathrm{cm}}=\frac{\sum_{1}^{\mathrm{n}} \mathrm{f}_{\mathrm{i}}}{\mathrm{n}}$

$\mathrm{f}_{\text {ckest }}=\mathrm{f}_{\text {int }[0.05]}$

The standard deviation $(\boldsymbol{\sigma})$, which represents the regularity and dispersion of the results in relation to the mean, was found from the square root of the sample variance, as it is shown in Eq. 4. The variation coefficient was calculated through the ration between the standard deviation and the mean, see Eq.5.

$\sigma=\sqrt{\frac{1}{n-1} \sum_{1}^{n}\left(f_{i}-f_{c m}\right)^{2}}$

Cve $=\frac{\sigma}{\mathrm{f}_{\mathrm{cm}}}$

Results from widely known international works $[17,18]$ indicate that
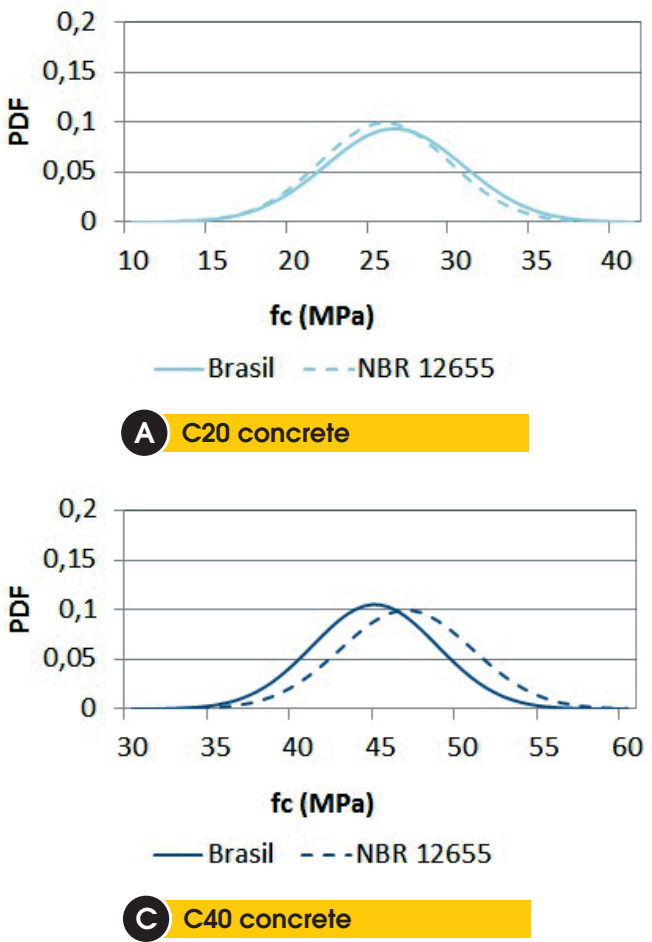

normal distribution is the one that best fits the description of concrete behavior, which was proven after successive fits using Easyfit software. It should be mentioned that in the existence of an efficient control, the strength values are grouped close to the mean and the distribution curve is high and narrow; on the opposite scenario, the strength values spread out and the curve becomes low and wide.

As the objective of this study was to obtain statistical descriptions that represent the sets of concrete produced in the country, the data from different construction sites were grouped and analyzed in blocks. Therefore, the national statistics were obtained from regional statistical weights, which were applied according to the number of samples available for each class in each region of the country. Eq. 6 shows the expression used in the weighting calculations.

$\operatorname{RESULT}_{\text {national }}=\sum\left(\operatorname{RESULT}_{\text {regional }}\right.$.WEIGHT $)$

It is worth mentioning this works also involved a previous statistical analysis of the samples in order to eliminate data that does not belong to the group (outliners). Figure 2 shows box-and-whiskers representations for the strength class samples studied in order to highlight the lower and upper barriers used to exclude spurious results.

\section{National results}

Figure 3 shows the probability distribution curves obtained from axial compression tests on cylindrical specimens of concrete molded at recipient and tested at 28 days, as well as the probability distribution

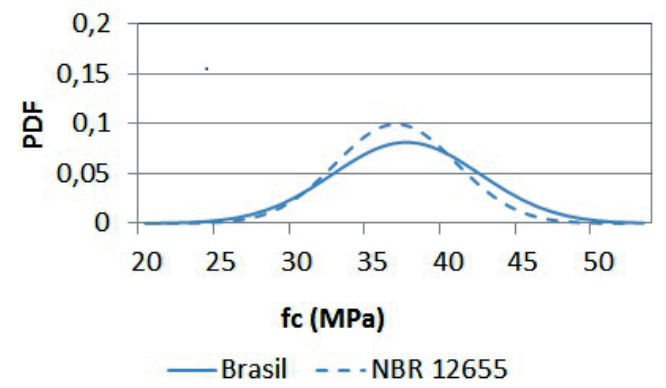

B C30 concrete

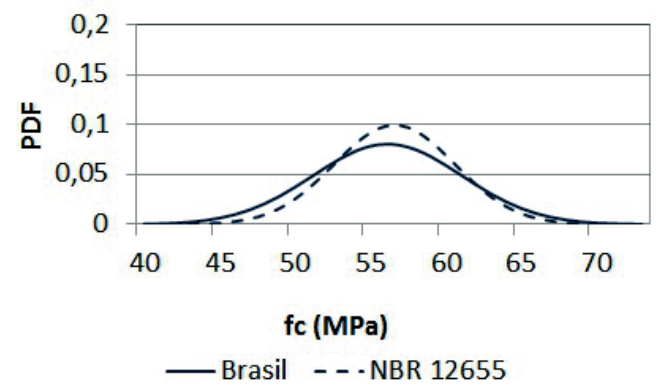

D C50 concrete

\section{Figure 3}

Comparison between the distribution function of concrete produced in Brazil and the ones foreseen in NBR 12655 
Table 3

Results of the concrete produced in Brazil

\begin{tabular}{|c|c|c|c|c|c|}
\hline Class & $\mathbf{f}_{\text {ckest }}(\mathbf{M P a})$ & $\mathbf{f}_{\mathrm{cm}}(\mathbf{M P a})$ & $\sigma(\mathbf{M P a})$ & Cve & $\begin{array}{c}\text { \% nonconforming } \\
\text { samples }\end{array}$ \\
\hline C20 & 19,2 & 26,2 & 4,3 & 0,164 & 8,3 \\
\hline C30 & 29,2 & 37,3 & 4,9 & 0,131 & 5,7 \\
\hline C40 & 38,5 & 44,7 & 3,8 & 0,084 & 6,9 \\
\hline C50 & 48,0 & 56,1 & 4,9 & 0,088 & 4,5 \\
\hline
\end{tabular}

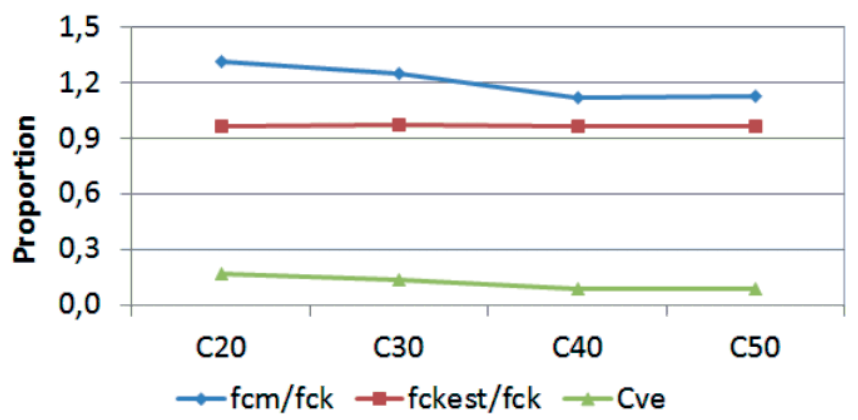

Figure 4

Summary of the results of the concretes produced in Brazil

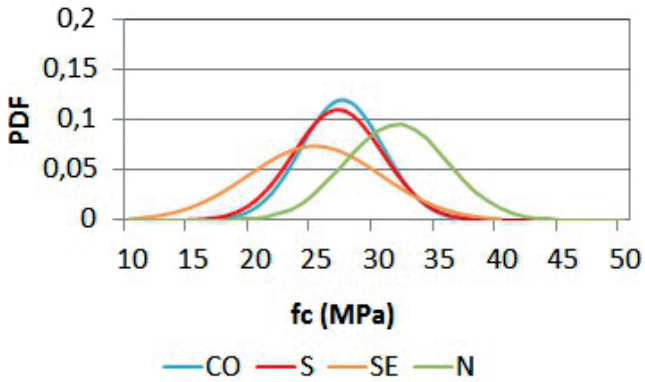

C20 concrete

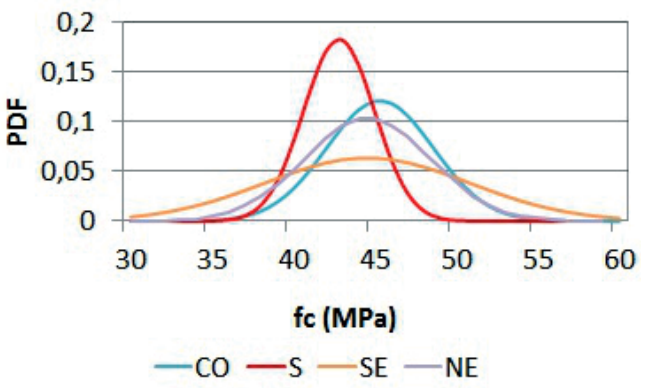

C40 concrete curves of the same concrete if it was to attend condition A of preparation as established in concrete's preparation, control and acceptance code [3]. It should be mentioned the results from each studied classes came from the same population, which they propose to represent. Concrete from classes $\mathrm{C} 20$ and C30 presents mean strength $\left(\mathrm{f}_{\mathrm{cm}}\right)$ and standard deviation $(\boldsymbol{\sigma})$ values higher than the ones predicted in the control and recipient norm [3]. Concrete from classes C40 and $\mathrm{C} 50$, on the other hand, presents mean strength $\left(f_{\mathrm{cm}}\right)$ value lower than the predicted value in the same norm.

Results obtained in terms of estimated characteristic strength $\left(f_{\text {ck- }}\right.$ est $)$, mean strength $\left(f_{\mathrm{cm}}\right)$, standard deviation $(\boldsymbol{\sigma})$, variation coefficient (Cve) and percentage of nonconforming concrete samples produced in Brazil are shown in Table 3. Results show that the estimated characteristic strength is lower than the specified characteristic strength $\left(f_{\text {ckest }}<f_{c k}\right.$ ) and that the percentage of nonconforming samples tends to be higher than the $5 \%$ stated in the norm.

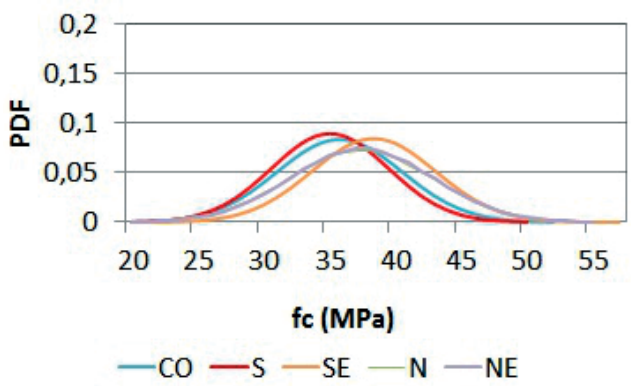

B C30 concrete

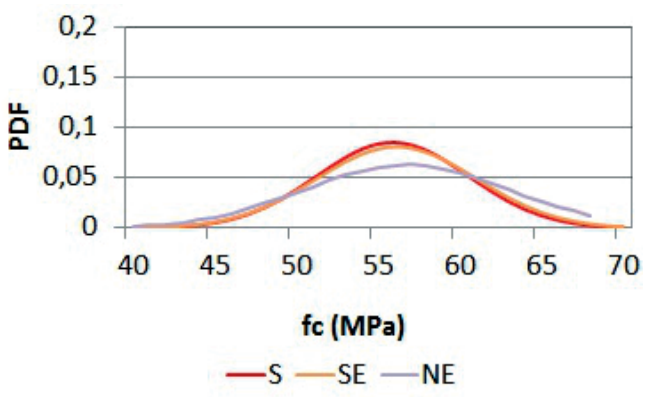

D C50 concrete

\section{Figure 5}

Comparison between the distribution functions of concrete produced in the different regions of the country 


\section{Table 4}

Summary of the concretes produced in the different regions of Brazil

\begin{tabular}{|c|c|c|c|c|c|c|}
\hline Class & Region & $\mathrm{f}_{\text {ckest }}(\mathrm{MPa})$ & $\mathrm{f}_{\mathrm{cm}}(\mathrm{MPa})$ & $\sigma(\mathrm{MPa})$ & Cve & $\%$ nonconforming samples \\
\hline \multirow{5}{*}{ C20 } & $\mathrm{CO}$ & 21,7 & 27,2 & 3,3 & 0,122 & 0,5 \\
\hline & $S$ & 20,9 & 26,9 & 3,6 & 0,134 & 1,1 \\
\hline & SE & 16,1 & 24,9 & 5,7 & 0,215 & 18,1 \\
\hline & $\mathrm{N}$ & 24,7 & 31,5 & 4,1 & 0,131 & 0,0 \\
\hline & - & - & - & - & - & - \\
\hline \multirow{5}{*}{ C30 } & $\mathrm{CO}$ & 27,9 & 35,8 & 4,8 & 0,133 & 9,2 \\
\hline & $S$ & 27,7 & 35,0 & 4,4 & 0,127 & 14,5 \\
\hline & SE & 30,6 & 38,4 & 4,7 & 0,123 & 3,3 \\
\hline & $\mathrm{N}$ & 28,4 & 37,4 & 5,5 & 0,146 & 12,5 \\
\hline & NE & 28,6 & 38,5 & 5,3 & 0,143 & 4,2 \\
\hline \multirow{5}{*}{ C40 } & $\mathrm{CO}$ & 39,9 & 45,3 & 3,3 & 0,073 & 2,1 \\
\hline & $\mathrm{S}$ & 39,2 & 42,8 & 2,2 & 0,051 & 7,4 \\
\hline & SE & 34,2 & 44,5 & 6,3 & 0,140 & 12,3 \\
\hline & $\mathrm{N}$ & - & - & - & - & - \\
\hline & $\mathrm{NE}$ & 38,2 & 44,6 & 3,9 & 0,086 & 10,5 \\
\hline \multirow{5}{*}{ C50 } & $\mathrm{CO}$ & - & - & - & - & - \\
\hline & $S$ & 48,2 & 55,9 & 4,7 & 0,083 & 6,7 \\
\hline & SE & 48,0 & 56,1 & 4,9 & 0,088 & 4,2 \\
\hline & $\mathrm{N}$ & - & - & - & - & - \\
\hline & $\mathrm{NE}$ & 46,4 & 56,8 & 6,3 & 0,111 & 9,1 \\
\hline
\end{tabular}

For each strength class of concrete, Figure 4 shows the ration variation between the mean strength and the specified characteristic strength $\left(\mathrm{f}_{\mathrm{cm}} / \mathrm{f}_{\mathrm{ck}}\right)$, the ration between the estimated characteristic strength and the specified characteristic strength $\left(f_{\text {ckest }} /\right.$ $f_{c k}$ ) and the variation coefficient (Cve). In this Figure is possible to observe the ration between the mean strength and the specified characteristic strength $\left(f_{\mathrm{cm}} / \mathrm{f}_{\mathrm{ck}}\right)$ and the variation coefficient (Cve) tend to decrease with increasing strength, while the ration between the estimated characteristic strength and the specified characteristic strength $\left(f_{\text {ckest }} / f_{c k}\right)$ tends to remain constant.

\section{Regional results}

Figure 5 presents the probability distribution curves obtained for concretes produced in different geographic regions of the country. It's evident that the concrete produced in different locations not always present similar behavior. Concrete produced in the South and Center-West regions, for example, tend to present less variability than those produced in the Southeast and Northeast regions.

Table 4 illustrate the results obtained in terms of estimated characteristic strength $\left(f_{c k e s t}\right)$, mean strength $\left(f_{c m}\right)$, standard deviation $(\sigma)$, variation coefficient ( $\mathrm{Cve}$ ) and percentage of nonconforming samples produced in the different regions of the country. Despite the dispersion of the results, it is evident that in most cases, the estimated characteristic strength tends to be lower than the specified characteristic strength $\left(f_{c k e s t}<f_{c k}\right)$ and that the percentage of nonconforming samples tends to be higher than $5 \%$.

Figure 6 indicates the variation of the ration between the mean strength and the specified characteristic strength $\left(\mathrm{f}_{\mathrm{cm}} / \mathrm{f}_{\mathrm{ck}}\right)$, the variation of the ration between the estimates characteristic strength and the specified characteristic strength $\left(\mathrm{f}_{\mathrm{ckest}} / \mathrm{f}_{\mathrm{ck}}\right)$ and the variation coefficient ( $\mathrm{Cve}$ ) for each strength class of concrete and geographic region of the country. This figures shows that, despite the relative dispersion of the results, it is possible to observe a declining trend of the ration between the mean strength and the specified characteristic strength $\left.\left(f_{c m} / f_{c k}\right)\right)$ and of the variation coefficient (Cve) with increasing strength.

\section{Comparison with previous results}

Figure 7 presents the probability distribution curves based on database from this study (2016), as well as the probability distribution curves based on database from Santiago and Beck [1] (2011). This figure let clear that in the interval of five years the concrete produced in Brazil presented an increase of mean strength, although the variability also increased. At first, this result is an indication that the dosing plants have centered the dosage of concrete on the mean strength and not in the characteristic strength anymore, as pointed out in previous works $[1,16]$ 


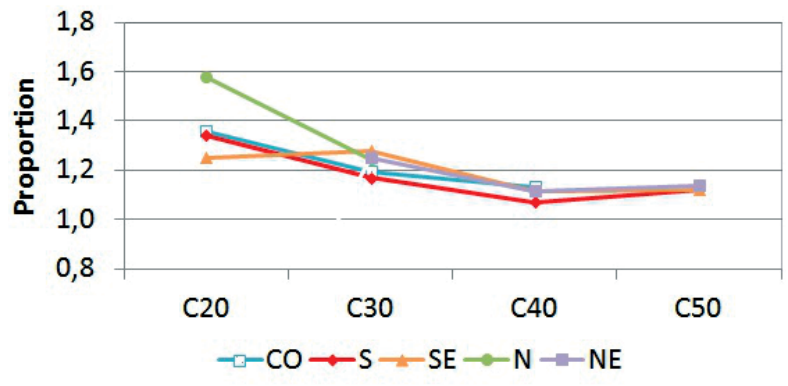

(A) $\mathrm{f}_{\mathrm{cm}} / \mathrm{f}_{\mathrm{ck}}$

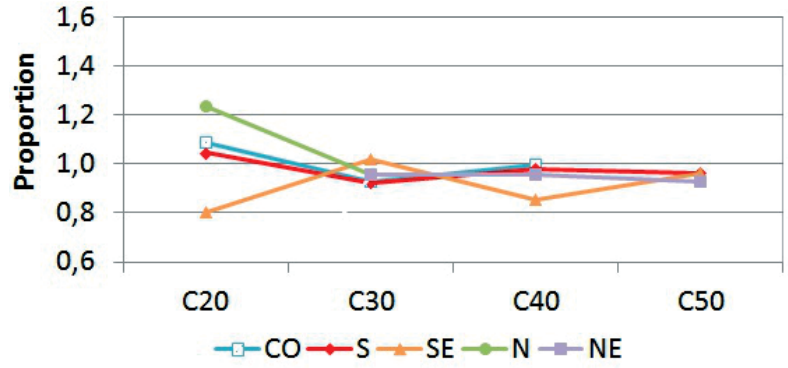

(B) $\mathrm{f}_{\text {ckess }} / \mathrm{f}_{\mathrm{ck}}$

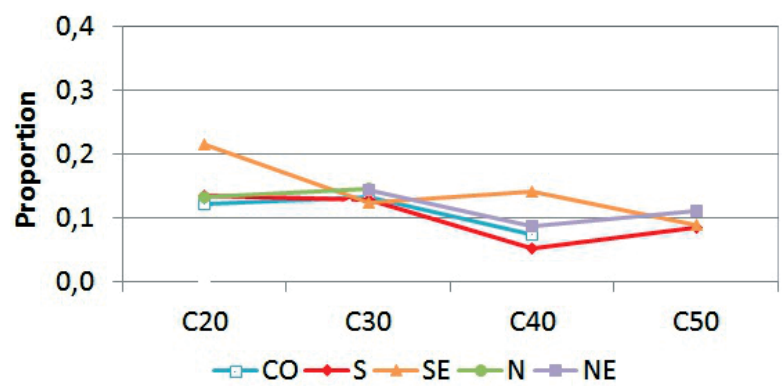

C) $\mathrm{Cre}$

\section{Figure 6}

Summary of the results of concrete produced in the different regions of the country

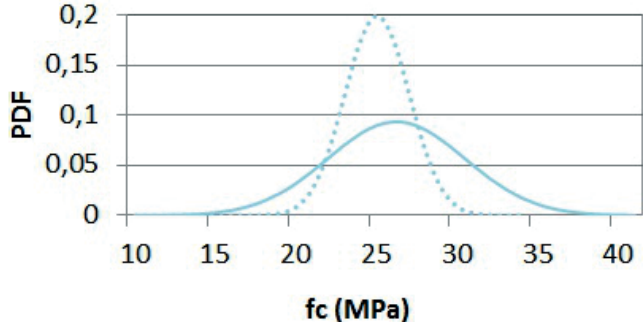

$-2016 \cdots \cdot 2011$

A $\mathrm{C20}$ concrete

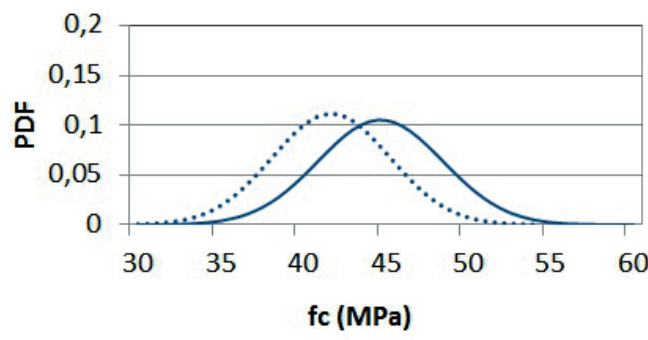

$-2016 \cdots 2011$

C $\mathrm{C40}$ concrete

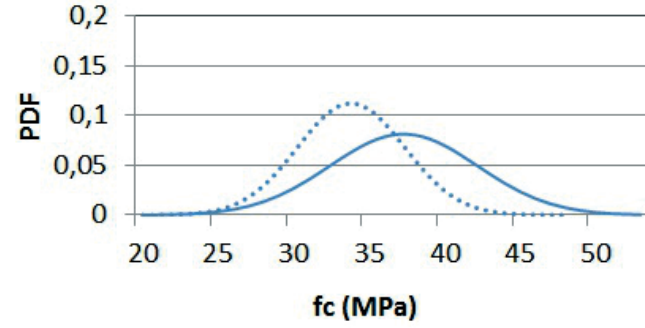

$-2016 \quad \cdots \cdot 2011$

B $\mathrm{C} 30$ concrete

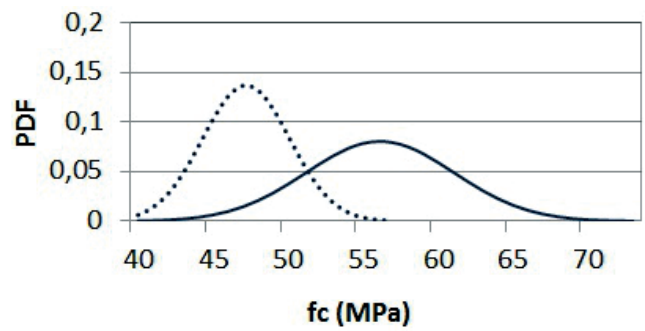

$-2016 \cdots \cdot 2011$

D $\mathrm{C50}$ concrete

Figure 7

Comparison between the distribution functions of the concrete produced in Brazil until 2011 and 2016 
Table 5

Results of the concretes produced in Brazil until 2011 and 2016

\begin{tabular}{|c|c|c|c|c|c|c|}
\hline Class & Year & $\mathbf{f}_{\text {ckest }}(\mathbf{M P a})$ & $\mathbf{f}_{\mathrm{cm}}(\mathbf{M P a})$ & $\sigma(\mathbf{M P a})$ & Cve & \% nonconforming samples \\
\hline \multirow{3}{*}{ C20 } & 2016 & 19,2 & 26,2 & 4,3 & 0,164 & 8,3 \\
\cline { 2 - 7 } & 2011 & 23,0 & 23,7 & 1,8 & 0,071 & 1,0 \\
\hline \multirow{3}{*}{ C30 } & 2016 & 29,2 & 37,3 & 4,9 & 0,131 & 5,7 \\
\cline { 2 - 7 } & 2011 & 27,9 & 28,0 & 3,6 & 0,105 & 9,0 \\
\hline \multirow{2}{*}{ C40 } & 2016 & 38,5 & 44,7 & 3,8 & 0,084 & 6,9 \\
\cline { 2 - 7 } & 2011 & 35,9 & 33,6 & 3,6 & 0,090 & 30,0 \\
\hline \multirow{2}{*}{ C50 } & 2016 & 48,0 & 56,1 & 4,9 & 0,088 & 4,5 \\
\cline { 2 - 7 } & 2011 & 42,4 & 41,1 & 2,9 & 0,062 & 84,0 \\
\hline
\end{tabular}

Table 5 present results obtained in terms of estimated characteristic strength $\left(f_{c k e s}\right)$, mean strength $\left(f_{c m}\right)$, standard deviation $(\boldsymbol{\sigma})$, variation coefficient (Cve) and percentage nonconforming concrete samples from Brazil until 2011 and 2016. The results show that, in general, there has been an increase of strength and a decrease in the percentage of nonconforming samples.

For each strength class, the Figure 8 indicates the variation of the ration between the mean strength and the specified characteristic strength $\left(f_{c m} / f_{c k}\right)$, the variation of the ration between the estimates characteristic strength and the specified characteristic strength $\left(f_{\text {ck- }}\right.$ $\left.{ }_{\text {est }} / f_{c k}\right)$ and the variation coefficient (Cve) according to the concrete produced until 2011 and 2016. It is possible to notice that the ration between the estimated characteristic strength and the specified characteristic strength $\left(f_{\text {ckesi }} / f_{c k}\right)$ tends to be constant only for concrete that belonged to the current database (2016).

\section{Conclusions}

This paper presented a study of concrete strength conformance from four distinct classes - C20, C30, C40 and C50 - produced in Brazil. This study was accomplished using a database of over twenty-seven thousand cylindrical specimens molded in loco and tested at 28 days with instantaneous and monotonic load.

The concrete from classes $\mathrm{C} 20$ and C30 presented mean strength

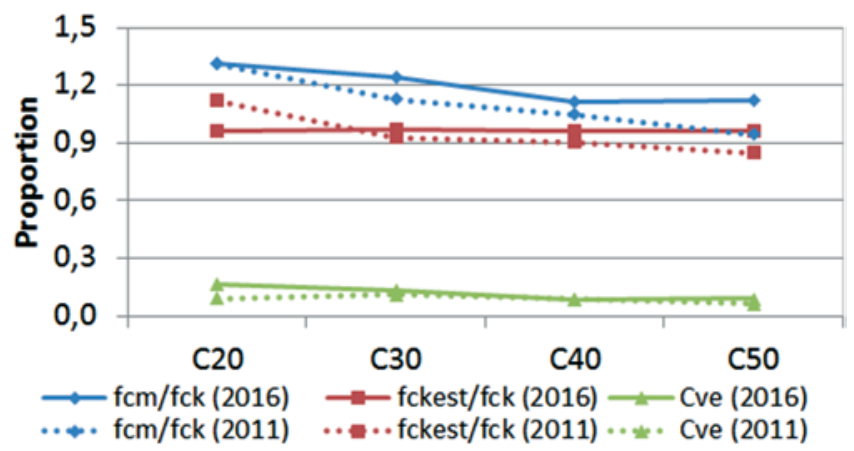

Figure 8

Comparison between the results of concrete produced until 2011 and the results of concrete produced until 2016 $\left(f_{c m}\right)$ values higher than the ones predicted in the concrete's preparation, control and acceptance code [3], while the concrete from classes $\mathrm{C} 40$ and $\mathrm{C} 50$ presented mean strength values lower than the ones predicted on this same code. For all the evaluated classes, the estimated characteristic strength tended to be lower than the correspondent characteristic strength $\left(f_{\text {ckest }}<f_{c k}\right)$, as well as the percentage of nonconforming samples and the standard deviation $(\sigma)$ values tend to be higher than the ones stipulated.

In relation to the regionalized results, concretes produced in the South and Center-West regions presented the lower variability than the ones produced in the Southeast and Northeast region. However, the percentage of nonconforming samples tended to be higher than $5 \%$ in all the regions.

In both national and regional results, it was possible to observe that the ration between the mean strength and the specified characteristic strength $\left(\mathrm{f}_{\mathrm{cm}} / \mathrm{f}_{\mathrm{ck}}\right)$ and the variation coefficient (Cve) tended to decrease with increasing strength, while the ration between the estimates characteristic strength and the specified characteristic strength $\left(f_{\text {ckest }} / f_{c k}\right)$ tended to be constant.

Although the results indicate that the concrete currently produced in the country present a slightly lower quality than the one predicted in the concrete's preparation, control and acceptance code [3], it is notable that along the last five years the material presented a substantial improvement in its behavior, considering the results published by Santiago and Beck [1].

The authors of this work are involved in a bigger project that aims the calibration, based on structural reliability, of the partial factors from Brazilian design codes. Therefore, this study of strength conformance of the concrete produced in the country is fundamental to achieve the final goal.

\section{Acknowledgments}

The authors are grateful to CNPq for the founding, as well as the professionals who provided the necessary data for the accomplishment of this work: Aline Heloá de Souza, André Moraes, Antônio Nereu Cavalcanti Filho, Cesar Pinto, Dagoberto Façanha, Deolinda de Oliveira Alves, Egydio Herve Neto, Fábio Luiz Willirich, Gezeli Bandeira de Mello, Girley da Silva Vespaziano, João Marcelo Linhares Feijão, Jônatas Moraes, Karoline A. Melo Moraes, Luis Guilhermo Vellacich, Luiz Felipe Ferrira Mello, Luiz Paulo Prigol, 
Marcos Aurélio Vianna de Escobar, Rafael Akira Akisue, Renato Trindade, Valdinei Jacques Alves and Vinícios Wagner Oliveira.

\section{References}

[1] SANTIAGO, W.C.; BECK, A.T. Estudo da (Não-)Conformidade de Concretos Produzidos no Brasil e sua Influência na Confiabilidade de Pilares Curtos. Revista IBRACON de Estruturas e Materiais, v.4, p.663 - 690, 2011.

[2] ASSOCIAÇÃO BRASILEIRA DE NORMAS TÉCNICAS. Concreto - Ensaios de compressão de corpos-de-prova cilíndricos. - NBR 5739, Rio de Janeiro, 2007.

[3] ASSOCIAÇÃO BRASILEIRA DE NORMAS TÉCNICAS. Concreto de cimento Portland - Preparo, controle, recebimento e aceitação - Procedimento. - NBR 12655, Rio de Janeiro, 2015.

corpos-de-prova cilíndricos. - NBR 5739, Rio de Janeiro, 2007

[4] ASSOCIAÇÃO BRASILEIRA DE NORMAS TÉCNICAS. Projeto de estruturas de concreto - Procedimento. - NBR 6118, Rio de Janeiro, 2014.

[5] BECK, A.T.; DÓRIA A.S. Reliability analysis of I-section stell columns designed according to new Brazilian building codes. J, of the Braz. Soc of Mech. Sci \& Eng. 30, 152-160, 2008.

[6] BECK, A.T.; DE OLIVEIRA, W.L.A.; DE NARDUM, S.; ELDEBS, A.L.H. Reliability-based evaluation of design code provisions for circular concrete-filled steel columns. Engineer Ing Structures, Elsevier, v.31, p.2299-2308, 2009.

[7] CHAVES, I.A.; BECK, A.T.; MALITE, M. Reliability-based evaluation of design guidelines for cold-formed steel I-concrete composite beams. J, of the Braz. Soc of Mech. Sci \& Eng. v.32, p.442-449, 2010.

[8] BECK, A.T.; SOUZA JR, A.C. A first attempt towards reliability-based calibration of Brazilian structural design codes. J, of the Braz. Soc of Mech. Sci \& Eng. v.32, p.119-127, 2010.

[9] PORRERO, K. Evaluación de los ensayos de resistencia del concreto. Boletín INME - Instituto de Materiales y Modelos Estructurales da Facultar de Ingenieria da Universidade Central de Venezuela, vol. 21, No. 72/73, p. 165-207, 1983.

[10] MEHTA, P. K.; MONTEIRO, P.J.M. Concreto: estrutura, propriedades e materiais. Editora Pini. São Paulo, 2008.

[11] MAGALHÃES, Fábio Costa; DE VASCONCELLOS REAL, Mauro; DA SILVA FILHO, Luiz Carlos Pinto. The problem of non-compliant concrete and its influence on the reliability of reinforced concrete columns. Materials and Structures, v. 49, n. 4, p. 1485-1497, 2016.

[12] SILVA FILHO, L. C. P.; HELENE, P. Análise de estruturas de concreto com problemas de resistência e dissuração. In: ISAIA, G. C. (Editor), Concreto: Ciência e Tecnologia. IBRACON, São Paulo, 2011

[13] CASTRO, E de. Estudo da resistência à compressão por meio de pequeno diâmetro e esclerometria. Dissertação de Mestrado. PPGEC/UFU. Uberlânida-MG, 2009.

[14] BORGES, M. L. Avaliação da qualidade de concreto produzidos em centrais dosadoras, misturados em caminhão betoneira e de concreto produzidos em centrais misturadoras. Dissertação de Mestrado. UFG. Goiânica-GO, 2009.
[15] VIEIRA FILHO, J. O. Avaliação da resistência à compressão do concreto através de testemunhos exterídos: contribuição à estimativa do coeficiente de correlão devido aos efeitos de broqueamento. Tese , USP - Universidade de São Paulo. São Paulo-SP, 2007.

[16] FARIA, R., 2009: Concreto não conforme, Revista Téchne, Edição 152, novembro 2009. Disponível em: <http://www. revistatechne.com.br/engenharia-civil/152/artigo156894-1. asp?o=r>. Acesso em: 16 janeiro 2016.

[17] ELLINGWOOD, B; GALAMBOS, T.V. Probability-based criteria for structural design. Structural Safety 1, p.15-26, 1982.

[18] NOWAK, A.S; SZERSZEN, M.M. Calibration of design code for buildings ( $\mathrm{ACl} 318)$ : Part 1 - Statistical models for resistance. ACI Structural Journal, v.100, n.3, p.377-382, 2003. 